\title{
Tolerating hate in the name of democracy
}

\section{Amanda R. Greene and Robert Mark Simpson ${ }^{1}$}

Abstract. This article offers a comprehensive and critical analysis of Eric Heinze's book Hate Speech and Democratic Citizenship (Oxford University Press, 2016). Heinze's project is to formulate and defend a more theoretically complex version of the idea (also defended by people like Ronald Dworkin and James Weinstein) that general legal prohibitions on hate speech in public discourse compromises the state's democratic legitimacy. We offer a detailed synopsis of Heinze's view, highlighting some of its distinctive qualities and strengths. We then develop a critical response to this view with three main focal points: (1) the characterisation of democratic legitimacy as something distinct from (and whose demands aren't identical with those of) legitimacy per se; (2) the claim that the requirements of democracy are hypothetical, rather than categorical, imperatives; and relatedly (3) the question of how we should reconcile the requirements of democratic legitimacy with the costs that may follow from prioritising democratic legitimacy. We argue that there are significant difficulties for Heinze's account on all three fronts.

\section{Introduction}

Free speech theory has been entwined with theories of democracy since at least the mid-20 ${ }^{\text {th }}$ century. American free speech jurisprudence has been shaped by Alexander Meiklejohn's view that democracy requires an informed electorate and an unrestricted flow of information, and building on this, scholars

\footnotetext{
${ }^{1}$ Thanks to Eric Heinze, Gavin Phillipson, and an anonymous reviewer from Modern Law Review for detailed and helpful comments on an earlier draft.
} 
like Robert Post and Weinstein have developed theories of the First Amendment grounded in ideals of democratic discourse and participation. ${ }^{2}$ The links between democracy and free speech are strongest in American legal theory, but they do important work elsewhere too. In Australia, for instance, free speech isn't explicitly asserted in the constitution, but courts have found an implied right to free political communication in the constitution's guarantee of a democratic government. ${ }^{3}$

Ronald Dworkin spells out the link between democracy and free speech in terms of state legitimacy. ${ }^{4}$ The state's enforcement of the law 'downstream', he argues, is only democratically legitimate if it allows unfettered debate 'upstream' over the ideals being enforced. In Hate Speech and Democratic Citizenship, Eric Heinze defends a novel version of this kind of view, arguing that the freedom to express our views - including views that would qualify as hate speech - must be "safeguarded not only as an individual right, but as an essential attribute of democratic citizenship" [4]. ${ }^{5}$ He sees robust free speech protections as "materially constitutive" of democracy [5], so a society that prohibits hate speech isn't fully democratic. Part of what distinguishes Heinze's view is that he thinks we shouldn't use a rights framework to articulate a democratic theory of free speech. Whereas liberals see rights as "shields against outright legislative... balancing of conflicting social interests", Heinze thinks this doesn't give due priority to free speech, because rights have become 'entrenched within balancing processes', in a way that makes it too easy to override them [9]. It's true that in most jurisdictions speech rights don't categorically constrain policy, and it isn't difficult to see why. Hate speech creates a conflict between some people's speech rights, and other people's right to be free from verbal abuse. In order to defend hard-line protections for free speech in the face of such conflict, the options are either to say that speech rights are infinitely stringent, or that there isn't in fact a right to be free from verbal abuse. Heinze offers us a way out of this dilemma. Free speech should be categorically protected, not because speech rights are

\footnotetext{
2 A. Meiklejohn, Free Speech and its Relation to Self-government (New York: Harper \& Brothers, 1948); R. C. Post, 'Racist speech, democracy, and the First Amendment' (1990), 32 William and Mary Law Review 267; J. Weinstein, 'Participatory democracy as the central value of American free speech doctrine' (2011) 97 Virginia Law Review 491.

${ }^{3}$ See G. Williams, Human rights under the Australian Constitution (Oxford: Oxford University Press, 2002).

${ }^{4}$ R. Dworkin, "Foreword" in Ivan Hare and James Weinstein (Eds.), Extreme Speech and Democracy (Oxford: Oxford University Press, 2009), v-ix.

${ }^{5}$ E. Heinze, Hate Speech and Democratic Citizenship (Oxford University Press, 2016). Emphasis in original. Note: subsequent page citations will be presented in-text as numbers in square brackets.
} 
infinitely stringent, but because we have an overriding commitment to living in a democracy, and free speech is an uncompromisable element of this. This view about the demands of democracy primarily applies to what Heinze calls Longstanding, Stable, and Prosperous Democracies (or LSPDs), as contrasted with fragile democracies and non-democratic states. This distinction represents an intriguing methodological innovation; an attempt to think abstractly about what democracy as such calls for [13], but without completely reverting to utopian ideal theory.

After presenting a synopsis of Heinze's view in $\$ 2$, we explore three main lines of criticism against it. In $\$ 3$ we explain how Heinze partitions the concept of legitimacy in order to isolate a notion of democratic legitimacy, and we argue that this unduly emphasises free public discourse as the defining feature of a democracy. In $₫ 4$ we raise some concerns with Heinze's reliance on the idea that the demands of democracy are hypothetically binding rather than categorically binding. While Heinze needs to say that democratic requirements are a merely hypothetical imperative, we show that this is a hard case to make. We also suggest some problems with Heinze's historical inductive argument that LSPDs are uniquely equipped to counter the negative consequences of hate speech. In $\$ 5$ we suggest that, given Heinze's view of democratic legitimacy, an LSPD that's responding to hate speech's targets must say that upholding democracy matters more than relieving these people's suffering. We raise some concerns about an understanding of democracy that has this implication.

\section{Synopsis}

Heinze's aim is to argue against hate speech bans, by which he means legal restrictions "on hateful (both verbal and non-verbal) expression" [19]. He thinks a state cannot restrict hate speech without thwarting its legitimacy as a democracy, because the prerogatives of free speech are an essential attribute of democratic citizenship.

This differs from a standard liberal view of expressive liberty, spelled out in terms of a right to free speech. And Heinze is critical of the methods liberals use in trying to identify the scope of speech rights. International human rights treaties are little help, because they don't really mean what they say. For instance, the ICCPR says "everyone shall have the right to freedom of expression", while also calling for the prohibition of "any advocacy of national, racial or religious hatred that constitutes incitement to 
discrimination, hostility or violence". ${ }^{6}$ Heinze argues that this doesn't represent any state's real stance on the scope of free speech, since every state permits some speech that promotes hostile views towards other nations [39-40]. He is also unimpressed by those who would allow common-law balancing processes to decide the scope of free speech rights. Advocates of this approach see it as a tonic to America's alleged 'free speech absolutism'. But according to Heinze, this mispresents the in-principle difference between constitutional and common law rights regimes. Fully absolute rights are inimical to any functional legal system, and the ability to resolve conflicts between presumptive rights isn't some special feature of common law systems. Rather, it is a basic function that all legal systems operationalise in their own way. The real challenge, as Heinze sees it, is identifying suitable limits and 'threshold norms', to constrain when and how people's expressive liberties can justifiably be overridden in the course of these balancing processes [43].

On its face this looks like a technical, legalistic challenge, but Heinze thinks we can address it in a philosophical way, by giving a conceptual analysis of democracy's "minimally necessary attributes and values" [44]. His claim, again, is that free speech is a constitutive aspect of being a citizen in a democracy, and not something that can be treated as another presumptive interest to be balanced against others. In Heinze's terms, democratic legitimacy requires respect for a citizen prerogative of non-viewpoint-punitive expression in public discourse [45]. 'Public discourse' here doesn't mean communication that occurs in public. Rather, it means expression whose message could - irrespective of its actual audience - be directed to, and of interest to, a wide audience [27]. ${ }^{7}$ Obviously there are borderline cases, but the point is that where expression does fall under this definition, the state cannot impose "viewpoint-selective penalties" on it, without undermining its legitimacy as a democracy [27].

If that is the domain in which the citizen prerogative applies, what exactly is the prerogative's content?

\footnotetext{
${ }^{6}$ International Covenant on Civil and Political Rights (1966, Articles 19.2 and 20.2). In a similar vein, the International Convention on the Elimination of All Forms of Racial Discrimination (1965) affirms free speech as a universal human right (Article 5.d.viii), while at the same time demanding the prohibition of "all dissemination of ideas based on racial superiority or hatred [and] incitement to racial discrimination" (Article 4.a).

7 “The sphere of democratic public discourse", Heinze says, "can be distinguished from face-to-face encounters such as individually targeted stalking, trespass, assault, harassment, or 'fighting words' situations" [29]. These things "do not become public discourse simply by being uttered in public places" [30]. And conversely, communication isn't located outside the realm of public discourse by virtue of being enacted in a private space [29].
} 
Heinze explains "non-viewpoint-punitive expression" like this:

Every legal norm supposes some viewpoint... A legal norm counts as non-viewpoint-punitive not by abstaining from a viewpoint, but when, taken within the legal system as a whole, it entails no penalty for the expression... of some contrary viewpoint. [21-22]

As an example, Heinze considers a norm forbidding cannabis production. This norm is non-viewpointpunitive if no part of the legal system penalises advocacy for legalizing the cannabis trade. And being nonviewpoint punitive, in this sense, is a legitimating condition for a democratic legal regime specifically. While there are other legitimating conditions that apply to all regimes, like refraining from violent persecution of citizens, these conditions aren't unique to democracy, whereas non-viewpoint-punitive public discourse is. Now, one might think that this misrepresents a typical feature of democracy as a conceptually essential feature. Aren't free elections the thing that constitutes a state as democratic? No. According to Heinze, voting is better understood as "a formalized procedure for speaking" [46]. Democracies restrict who votes (e.g. not enfranchising children), hold elections only intermittently, and apply procedures that imperfectly translate preferences into electoral results. And of course there are also sham democracies whose electoral practices are superficially democratic, but covertly authoritarian [48]. As integral as voting is to democratic citizenship, then, it cannot be the essential attribute of democratic citizenship. Instead, according to Heinze:

\footnotetext{
There must be some attribute of citizenship even more primordial than voting, which we carry around with us always and everywhere... That attribute, the citizen prerogative of non-viewpointpunitive expression within public discourse... cannot legitimately be regulated for the sake of democracy because it signally constitutes democracy. [47]
}

One way to unpack the idea is by drawing a contrast with anti-democratic regimes that flatly oppose government by the people. "Under a totalitarian regime", Heinze says, "all non-trivial laws or policies... tacitly entail a distinct, concomitant rule, namely, that such law or policy is not to be publicly criticized"; this represents not just an impairment of public discourse, but its annihilation [56]. Democracy inverts this. In the totalitarian state nothing in the prevailing social order can be criticised. But democracy is characterised by the ideal of citizens being able to criticise anything about the prevailing social order, including all state policies and the conduct of government officials. A more elusive part of Heinze's view on this is the idea that free speech is more primordial to democracy than voting. He conceives of open 
public discourse as "the original and ongoing source of the constitution" - or "the constitution of the constitution" - in a democracy [82]. The constitution of a democratic state's legitimacy isn't ultimately grounded in votes or elections; rather, it is "constituted through nothing but an ongoing process of public discourse" [6]. Of course the claim isn't that the citizens all have a public debate and jointly decide to endorse the constitution. Again, this is a conceptual claim. It is best understood in contrast with the totalitarian regime that aims to remove the possibility of the citizenry withdrawing support for the regime. By contrast, a democracy should protect the possibility of the people withdrawing support, and the guarantee of people being able to express any viewpoint in public is the primary, axiomatic commitment through which a democratic state safeguards this possibility. ${ }^{8}$

The underlying concerns here about totalitarianism are entirely reasonable. But so too are concerns that are stressed by advocates of hate speech bans. Whatever democratic legitimacy can be bought by strong protections for free speech would presumably be forfeited if it turns out that unfettered public discourse makes it possible for genocidal social movements to germinate. One might assume, then, that considerations of democratic legitimacy cut both ways, giving us reasons to safeguard free speech, but also reasons to limit it.

Not quite, Heinze says. It's true that many states do have good reasons, related to these concerns, to regulate expressive liberties. But those reasons derive from a prior suite of norms related to the requirements of security. Heinze allows that the regulation of hate speech is justifiable in principle, for the sake of security. But to infer from this that all democratic states have grounds for banning hate speech is to commit what Heinze calls the Weimar fallacy [131]. He explains that

The Weimar Republic, albeit constitutionally democratic, was certainly not longstanding, having emerged... as an historical novelty largely unwelcome among Germans... [Its] constitution was

\footnotetext{
${ }^{8}$ Here Heinze echoes Rousseau's model of a free association, in which periodic public assemblies are guaranteed so that citizens can air their views on all aspects of government, including the constitution itself. In The Social Contract, Rousseau says, "These assemblies, which have no other object than to maintain the social treaty, ought always to open with two motions which it should be impossible ever to omit, and which ought to be voted on separately: The first: whether it please the Sovereign to retain the present form of Government? The second: whether it please the People to leave its administration to those who are currently charged with it? ... In the state there is no fundamental law that could not be revoked, not even the social pact. For if all the Citizens were to assemble to break this pact by a common accord, there can be no doubt that it would be most legitimately broken". J.-J. Rousseau, "The Social Contract" and Other Later Political Writings, Ed. Victor Gourevitch (Cambridge University Press, 1997) 119-120.
} 
implemented in spite of a population untrained in practices of democratic norms... Weimar's political parties reflected, and pursued, a popular majority sentiment aiming to eliminate democracy altogether.

In states on the brink of security breakdown, as the Weimar Republic was throughout its existence, it is acceptable, at least in principle, to implement policies, including hate speech bans, aiming at basic security [71]. The Weimar fallacy involves thinking that all states are always in these conditions. Against this, Heinze argues that there are some states - LSPDs, i.e. Longstanding, Stable, and Prosperous Democracies - with "sufficient legal, institutional, educational, and material resources to admit all views into public discourse" while also being "equipped to protect vulnerable groups from violence or discrimination" [70]. ${ }^{9}$ Heinze uses The Economist's 'Democracy Index' as a guide to which states fall in this class. The 2013 report recognises twenty-five 'full democracies', with Norway at number one, and Spain scraping in at twenty-five [70]. In reference to these states, Heinze declares that

The LSPD represents an historically distinct form of society. Hatred and its expression by no means disappears. But a... democratized society turns hate speech into a different type of phenomenon. Prejudice continues to work its way through society, but in tandem with multilateral counter-forces, both official and informal, which can be... harnessed against hatred without the state needing to diminish citizen speech prerogatives. [72]

In short, Heinze thinks LSPDs can overcome identity-prejudice without the legal silencing of bigotry, and that it's thus possible in an LSPD to have an uncompromised form of democratic legitimacy, without running the risk of giving birth to genocidal social movements. Having said that, Heinze doesn't think LSPD governments can just revert to laissez faire disengagement, or adopt a stance of value-neutrality in issues around identity-prejudice. 'Democratic governments rightly can and do sponsor 'one-sided'

\footnotetext{
${ }^{9}$ Heinze wants to maintain that in an LSPD, national security concerns would allow us to override democracy's legitimating conditions only under formally declared states of emergency, and only to the extent dictated by the emergency. Thus the Weimar fallacy involves thinking that security concerns override the demands of democracy in a way that's routine, rather than confined to states of emergency. Of course one might dispute whether this is a fallacy. Carl Schmitt famously claimed that modern states' apparent resolution of the immediate problems of security is necessarily insecure and contingent, and that the proper scope of emergency powers cannot be adequately addressed by constitutional limitations. For a discussion of Schmitt on this point, see R. Slagstad, 'Liberal constitutionalism and its critics: Carl Schmitt and Max Weber' in Rune Slagstad and Jon Elster (Eds.), Constitutionalism and Democracy, Revised Edition (Cambridge: Cambridge University Press, 2008) 103.
} 
messages promoting pluralism", he says, and this is consistent with the legitimating requirement "not to punish odious speakers" [113]. The LSPD must proactively work at preventing hate speech from eroding democracy, just not by censoring hate speech in public discourse. ${ }^{10}$

One rejoinder to all this is: what about the harm that hate speech does to its targets, even in LSPDs where genocidal movements aren't an immediate threat? On Heinze's account, it's fine for LSPDs to regulate hate speech that's used to harass particular individuals; such hate speech is directly harmful in ways that can be evidentially substantiated [126]. But he rejects the claim that hate speech also manages to harm its targets by indirectly contributing to harmful systems of social inequality. He says we lack the relevant evidence: "LSPDs are the most empirically surveyed societies in history", and yet "despite decades of pro-ban law and policy... no empirical evidence has, in any statistically standard way, traced hatred expressed within general public discourse to specifically harmful effects" [126-27]. ${ }^{11}$ In the absence of such evidence, Heinze sees those who regard hate speech as the source of pervasive indirect harms as effectively redefining social harms, so that it becomes true by definition that to be a member of a subordinated group targeted with hate speech is to suffer a harm that justifies a legal remedy [153-62]. And this unmooring of claims about harmful effects from empirical evidence demonstrating those effects is a dangerous method, in multiple respects. It can be used by reactionaries, just as easily as progressives, to conjure up justifications for the silencing of views they oppose under the pretext of harm-prevention. And even when it's just in the hands of progressives, it can be used to attribute blame for complex social problems to convenient scapegoats - those who express identity-prejudicial views in a crude and vulgar fashion - diverting effort and attention from various other sources of social inequality [159].

\footnotetext{
${ }^{10}$ For discussion of what kind of pro-pluralism social messaging the state might engage in, and how it might go about this messaging work, see for instance C. Brettschneider, When the State Speaks, What Should It Say? How Democracies Can Protect Expression and Promote Equality (Princeton: Princeton University Press, 2012) and K. Gelber, “"Speaking back”: the likely fate of hate speech policy in the United States and Australia' in Ishani Maitra and Mary Kate McGowan (Eds.), Speech and Harm: Controversies over Free Speech (Oxford: Oxford University Press, 2012) 50.

11 One way to read Heinze's point is as saying that if hate speech did have a tangibly harmful effect, we would have acquired evidence of this by now. But Heinze doesn't need to (or want to) formulate the argument in that way. The lack of evidence by itself wouldn't entitle us to conclude that hate speech in LSPDs is harmless.
} 


\section{Why accept Heinze's account of legitimacy?}

Heinze's account of legitimacy raises plenty of questions. In this section we examine three areas where difficulties arise, and where we think more needs to be said. The first concerns Heinze's rejection of liberal accounts of legitimacy. He posits an extra-legal substrate of social order, "something that is necessarily presupposed as the original and ongoing source of the constitution" [82]. According to Heinze this "primordial" zone must contain a certain kind of norm: one that stands outside the legal system and is thus capable of legitimating that system. Without this conceptually prior legitimation zone, we would need a legal system to somehow validate its own legitimacy. Heinze thinks that a legal system cannot itself encompass this zone. The legal regulation of norms in this zone is a kind of category mistake, according to Heinze, because it means that whatever is in the zone isn't then able to legitimate the legal system.

Having characterised this primordial zone by its legitimating function, Heinze asks what could fill it. It cannot be individual rights, he says, because rights are inevitably curtailed by the very existence of law: "an absolute freedom must by definition supersede all competing interests", and hence "no individual freedom can be absolute under any legal system without destroying the entirety of the system" [40-41]. In liberal regimes, the curtailment of individual rights necessarily involves a jurisprudence of balancing. The balancing occurs either through the application of a harm principle, or through legal proceduralism that is based on a plurality of values. In either case, the balancing limits individual rights, and so rights-based norms cannot occupy the primordial zone of legitimation. By contrast, Heinze thinks norms of citizenship can occupy this zone. He explains why using a conceptual argument.

A human right must routinely be modulated [by law] in terms of its greater and lesser exercises.

Rarely if ever can it make sense that democratic citizenship could be modulated in that way. It is a conceptual impossibility, a conceptual nonsense, that one could ever abuse or misuse one's citizenship, no matter how hard one tries to do so. My liberty to swing my fist may stop at your nose, but there is no such thing as swinging one's citizenship in any such way. [91]

We should note, firstly, that the view Heinze calls nonsensical here - that citizenship can be abused; that it is, in this sense, similar to a right - is actually fairly commonplace. Political theorists like Habermas and Rawls think that norms of citizenship constrain our political activities by imposing duties of civility and 
other duties relating to communication. ${ }^{12}$ Heinze also tries to distinguish citizenship from rights by saying that citizenship cannot be exhausted by its legal components, the "purely administrative by-product of birth and naturalization certificates" [92]. But we don't see why proponents of a standard liberal view cannot say the same about rights. Schematically, the distinguishing feature of citizenship, for Heinze, is meant to be that it generates prerogatives. But it's unclear how an appeal to this concept resolves the issue. Presumably, a prerogative is a standing permission for an individual to engage in an activity, with the presumption that this won't be legally abridged [45-51]. But again, it's not clear why prerogatives thus understood are immune to problems of legislative balancing in a way that's structurally different to rights. And Heinze cannot explain the difference in terms of whether the law must refrain from abridging it in order to be legitimate, since this is supposed to be the conclusion rather than a premise in the argument. In short, we cannot distinguish citizenship from rights just by claiming that it involves a prerogative, and then defining a citizen prerogative as having whatever normative feature avoids the legal embeddedness that he's ascribing to rights.

To see how a liberal free speech right could, in principle, occupy the primordial legitimating zone that Heinze identifies, consider the position recently advanced by Seana Shiffrin. ${ }^{13}$ She argues for an individual right of expression, grounded in our fundamental human interest in being able to disclose our thoughts and feelings authentically to others. In other words, Shiffrin locates the right to free speech outside of the legislative and judicial process of balancing harms. In doing so, she appeals to an underlying, fundamental source of justification in a way that is structurally similar to the sort of justification that Heinze says is only available with a speech prerogative. Heinze thinks this is untenable. But as we've said above, the argumentative burden of explaining exactly why a prerogative can fill the primordial zone, and a right cannot, still remains. Even if Heinze is right to posit an extra-legal zone of legitimation, he doesn't show why the existence of such a zone entails that the prerogatives of democratic citizenship are superior to rights in occupying that zone.

Another questionable aspect of Heinze's approach to legitimacy is his method of partitioning. He thinks some aspects of legitimacy can be isolated: specifically, democratic legitimacy can be isolated. To begin with, Heinze's methodology in theorizing about the various factors involved legitimacy isn't clear.

\footnotetext{
${ }^{12}$ J. Habermas, Between Facts and Norms: Contributions to a Discourse Theory of Law and Democracy (Cambridge: MIT Press, 1996); J.

Rawls, Justice as Fairness: A Restatement, Ed. Erin Kelly (Cambridge: Harvard University Belknap Press, 2001).

${ }^{13}$ S. V. Shiffrin, Speech Matters: On Lying, Morality, and the Law (Princeton: Princeton University Press, 2014).
} 
He offers a list of possible factors, saying that

Many factors legitimate a state as a state... In examining something as complex as a state's overall political legitimacy, we would ordinarily consider a variety of factors... commitment to rule of law... distributive justice [etc.] ... Refraining from torturing prisoners, guaranteeing fair trials, or avoiding famines legitimate a state as a state... Any number of fundamental interests might be cited to test the legitimacy of states as states. [45-46]

Heinze then tries to sort this collection of multiple factors into what is and isn't distinctive of a democracy, by using the following test: could we imagine their fulfilment (e.g. criminal justice, rule of law) without positing a democratic constitution? We're doubtful, though, that the democratic and nondemocratic legitimating factors can be so easily separated via this imaginative exercise. At the very least, Heinze is downplaying a long tradition of theorists who seek to ground state legitimacy in popular participation. His partitioning method stands in need of further defense, then, if it is supposed to establish that there is a bright line between what legitimates a state as a state per se, and what legitimates it as a democracy.

With this concern hovering in the background, what Heinze does next with his partitioning is dubious. He uses it to isolate democracy as one dimension of legitimacy, and to say that it applies only conditionally to the class of democratic states: if a society is a (stable, prosperous, etc.) democracy, then it must fulfil democracy's legitimating conditions, including an individual expressive prerogative. This conditional application is a problem though, precisely because of the partitioning. Notice that Heinze's definition of "stable" requires that "victims of hate crime can be protected without constraining public discourse" [73]. Any LSPD state is thus, by definition, able to preserve democratic legitimacy without compromising state legitimacy, which means that, by definition, securing democratic legitimacy doesn't compromise state legitimacy. But then the justification for applying the norm seems tautologous: in the cases where democratic legitimacy is available without compromising state legitimacy, democratic legitimacy is available without compromising state legitimacy. Given the tight link between being a LSPD, and being bound by a specific legitimating condition - namely, an expressive prerogative - the scope of the norm's application risks being merely stipulative. ${ }^{14}$

\footnotetext{
${ }^{14}$ At one point Heinze says that if harmful effects of hate speech are empirically demonstrated in State X, what we learn isn't that there is one LSPD that disconfirms the claim that LSPDs are immune to the harms of hate speech, rather, we learn that X isn't
} 
Our third critique of Heinze's approach to legitimacy concerns his homing in on free public discourse as the essence of democratic legitimacy. Heinze rejects an attitude of "intractible openendedness" in defining democracy, which he finds in the work of David Richards [43]. He also says that a criterion based on popular support is insufficient for defining democracy, as some popular 'democratic regimes' are merely sham democracies [44]. But these points only indicate that there $i$ some essential element of democracy. They don't yet favour Heinze's view about expressive prerogatives being that essential element.

One rationale for Heinze's view comes into focus when he says "all democratic constitutions confirm the possibility of their abolition or amendment", and that "on their own terms, that can only mean through public discourse" [6]. The logic is that a constitution isn't democratic if the people couldn't alter it, and unfettered public discourse is necessary in order for the people to do this. But this doesn't seem like a good basis for rejecting theories that ground democratic legitimacy elsewhere, e.g. in ideals of moral equality or collective self-determination. Some authors think that a constitution isn't democratic if its support comes from a population in which certain groups are subordinated, or in which material conditions stand in the way of the people's collective self-determination. In order to reject these other candidate ideals as constitutive legitimating norms of democracy, Heinze relies on the claim that we can imagine a democratic constitution without their realization. But that risks begging the question. Each of those theories understands its respective ideal as corresponding to what democracy truly is, and accordingly, denies that we can imagine the realization of the relevant ideal without democracy. It isn't clear what Heinze wants to say - or can say - to justify his setting aside all the alternative "essences" of democracy in favor of his preferred essence.

In the end, Heinze must be combining a theory of what constitutes democracy with a theory of

actually an LSPD after all [81]. From Heinze's perspective, his claims about the special legitimacy conditions that apply in LSPDs aren't just definitional stipulations, they're inferences that can be reasonably drawn from social scientific studies of the communicative dynamics of public discourse in LSPDs. But the empirical and stipulative elements here seem to run together. First, Heinze characterizes LSPDs as a special kind of democracy, subject to special legitimating conditions. Then the key empirical claim - that hate speech doesn't bring about pervasive harms to its targets in LSPDs - is defended by appeal to empirical observation about LSPDs, including the fact that no good evidence of such an effect has yet been presented. But then the final, crucial claim - that if such evidence did turn up, the society in question wouldn't count as an LSPD - makes the earlier premises about the special powers of LSPDs true by definition. 
what makes democracy legitimate. ${ }^{15} \mathrm{He}$ isn't alone in this move. Democratic theorists as different as Schumpeter and Habermas hold that there is an internal conceptual relation between what constitutes a democracy and what legitimates a democracy. ${ }^{16}$ But other defenders of this 'constitutive' understanding of democratic legitimacy recognize the burden this approach carries, which is to explain why democracy is of utmost value even when its prioritization threatens other political values. This in turn requires explaining how democracy's value relates to other political values, without presuming that its norms already apply. While this is a difficult challenge, Heinze doesn't attempt to address it, in contrast to other democratic theorists. For instance, Thomas Christiano says that justice consists of public equality, and that democracy is partly constitutive of justice, because it is the only adequate realization of public equality. ${ }^{17}$ Joshua Cohen argues that what is fundamental to democracy is deliberative inclusion: a system that treats everyone as free and equal participants in decisions aimed at the common good. ${ }^{18}$ If democracy is to be characterized conceptually by ideals like public equality or deliberative inclusion, it follows that what legitimates democracy is realizing the relevant ideal as much as possible. But as Christiano and Cohen both appreciate, the devil is in the details of 'realize as much as possible'. For example, Cohen admits that absolutism about democratic ideals may have costs that come into conflict with the values that animate our allegiance to democracy in the first place. He says "common foundations [of substantive requirements of justice] in deliberative democracy do not provide any insurance against conflict [between the values] in practice". ${ }^{19}$ Cohen thinks that affirming common foundations in theory turns out to exert valuable practical pressure to accommodate the different requirements, even though the scope of accommodation is "a function of politics". ${ }^{20}$ More can be said, but the point is that any constitutive approach to theorising democratic legitimacy must reckon with this sort of problem directly.

\footnotetext{
15 This is true, notwithstanding Heinze's discussion of optimizing versus legitimizing conditions [118-120].

${ }^{16}$ Habermas, n 12 above. Schumpeter, in the course of rejecting the classical doctrine of democracy in favor of his own elite competition theory, says that the definition of democracy is not independent of arguments for democracy. J. Schumpeter, Capitalism, Socialism, and Democracy, 5th edn (London: Allen and Unwin, 1976) 243.

17 T. Christiano, 'An egalitarian argument for a human right to democracy' in Cindy Holder and David Reidy (Eds.), Human Rights: The Hard Questions (Cambridge: Cambridge University Press, 2013) 301.

18 J. Cohen, 'Procedure and substance in deliberative democracy' in Seyla Benhabib (Ed.), Democracy and Difference: Contesting the Boundaries of the Political (Princeton: Princeton University Press, 1996) 95.

19 ibid 108-109.

20 ibid 109.
} 
Indeed, Cohen's approach seems to achieve what Heinze says is impossible: it defends the kind of absolutism Heinze advocates, but in terms of an "expressive interest" - one that's implied by the democratic ideal of deliberative inclusion. Cohen says that "content regulation is to be rejected because of the reasons for speech that are captured in the expressive interest, and not simply because such regulations prematurely foreclose public discussion". ${ }^{21}$ Heinze rejects arguments that defend expressive prerogatives in terms of autonomy and personhood, claiming that they rely upon a questionable ontology of agency. But this is not true of Cohen. In a Rawlsian spirit, Cohen argues that individual liberty and the democratic prerogative of expression are inseparable elements that together form a moral-political nexus of justification. This nexus of justification has one foot inside the legal system and one foot outside of it, and since the norms are reflected in the legal system without being exhausted by it, an account like Cohen's can handle the primordial zone problem that Heinze presses. ${ }^{22}$

Nevertheless, Heinze fiercely resists any theoretical integration of a liberal and democratic prerogative of expression. He says, "Liberalism posits freedom as constitutive of law's legitimacy and citizenship as derivative of it; democracy posits citizenship as constitutive of law's legitimacy and freedom as derivative of it"; he sees "two spheres which cannot wholly reduce to each other" (98). Contrary to what Heinze says, though, Cohen offers us a plausible account of how freedom and citizenship can be integrated in a theoretically adequate way. Moreover, at one point Heinze himself characterizes citizenship as having elements that are inscribed within the legal system: he says that voting is a necessary part of democratic citizenship, and the legal right to vote has contours that vary according to the administrative setup of the legal system [48-49]. It remains unclear, then, why Heinze is entitled to reject the combined liberal-democratic prerogative that is represented by Cohen's 'expressive interest'.

\footnotetext{
${ }^{21}$ J. Cohen, 'Democracy and liberty' in Philosophy, Politics, Democracy: Selected Essays (Cambridge: Harvard University Press, 2009) 251.

${ }^{22}$ Cohen ultimately advocates a form of balancing, but with stringent weighting on the side of free expression: "the expressive interest may be overridden, but the conventional rationales for regulation fail to acknowledge it, and thus fall afoul of the requirements of deliberative inclusion. More particularly, though the connections with the expressive interest do not settle the issue, they do help to increase the burden of argument that must be carried in justifying such regulations... defenders of regulations must make a more compelling showing of [harms] and not simply advance the speculative arguments that are commonly proposed" (ibid 253). Thus Cohen reaches the same conclusion as Heinze: until harms can be shown, the democratic society shouldn’t limit free expression.
} 


\section{Why aspire to Heinze's vision of democracy?}

For most of us, in most contexts, today, the question of whether we should favour democratic over nondemocratic forms of government is one whose answer we assume without argument. As Niko Kolodny says, claims about just government are often equated with claims about democratic government, not only by the folk, but also by political theorists. ${ }^{23}$ However, democracy as Heinze conceives of it doesn't serve as a source of shared assumptions for political discourse in this way. He presents a bold vision of democracy, giving a primacy to expressive liberty that goes beyond what many democratic theorists would endorse. The question, then, is: must we embrace this vision of democracy, or are there other acceptable visions, ones that allow us to sacrifice a measure of democratic legitimacy (as Heinze conceives of it) in order to prioritise other ideals? 'To phrase it another way: is Heinze's version of democratic legitimacy a categorical imperative, or just a bypothetical imperative, whose demands can be set aside at a pinch, just like the demands of other hypothetical imperatives? ${ }^{24}$

Heinze addresses this at a few points, and at first blush his view seems clear-cut: "I am assuming a democratic order as a hypothetical [and] not as a categorical political imperative" [55]. He also makes this point by contrasting the categorically binding demands of human rights norms with the non-binding demands of democratic norms. Rights against torture, he says, "inhere in humans regardless of whether they live in a democracy, an absolute monarchy, or a dictatorship" [52]. By contrast, when we identify norms essential to democracy, "this does not require that we posit democracy as superior to other forms of government"; rather, it's just about stating "which norms must obtain if a society is to be democratic" [52]. We see a momentary lapse in this stance when Heinze says we must resist complacency in the face of anti-democratic movements, and warns us that famines still occurred large non-democratic societies into the $20^{\text {th }}$ century [120]. These remarks seem to be premised on the view, backed by Amartya Sen's well-known findings, that democratic regimes categorically are better than the alternative in some essential governmental tasks, like preventing starvation. ${ }^{25}$ On the whole, though, Heinze is good to his word in not trying to press the case for democracy against its rivals; besides the allusion to Sen's view about democracy's utility in preventing famine, he doesn't tout democracy's merits, instrumental or otherwise.

\footnotetext{
${ }^{23}$ N. Kolodny, 'Rule over none I: What justifies democracy?' (2014) 42 Philosopby \& Public Affairs 195-196.

${ }^{24}$ For an earlier discussion along similar lines, see Post, n 2 above.

25 A. Sen, Poverty and Famines: An Essay on Entitlement and Deprivation (Oxford: Oxford University Press, 1981).
} 
Ultimately, then, Heinze is only really attempting to persuade us about what democracy's normative requirements are. He isn't attempting to establish that all states are subject to those normative requirements.

The difficulty with this as an argumentative strategy, however, is that there isn't one universallyapplicable set of norms that a state is subject to in virtue of descriptively qualifying as a democracy, or that can be held up as democracy's requirements, full stop. This is true by Heinze's own reckoning. For instance, while he shares Dworkin's view about the illegitimacy of hate speech bans in a democracy, he calls Dworkin 'naïvely universalistic' for thinking we can make across-the-board generalisations about this issue. What Dworkin ought to have seen, instead, is that different responses to hate speech are apt for different democracies in different circumstances [11-12]. The whole idea of the LSPD, as a device in Heinze's analysis, is a way of working out this approach, in which we think about the requirements of democracy in terms of what's achievable in real historically-located regimes. What's achievable in an LSPD is different to what's achievable in a state with a brittle democratic culture. The latter may still count as a democracy in some sense, but less can be demanded of it - in the name of living up to its democratic status - than what can be demanded of an LSPD.

What this means, then, is that there are different ways of being a democracy - the LSPD way and the sub-LSPD way - and different sets of requirements that a state might be subject to as a democracy. The menu of possible ways of being a democracy expands further when we drill down into the category of LSPDs. Heinze thinks a state that scores highly on most indices of democratic functioning, like Sweden, loses a portion of its democratic legitimacy due to its restriction of hate speech, but that it remains a democracy in good standing on the balance of considerations. As long as "such incursions into essential citizen prerogatives remain generally rare", he says, "the democracy remains intact, any pro tanto de-legitimacy being minimal" [119]. On this front too, then, we see different sets of norms that a regime can conform itself to, which are consistent with that regime retaining a democratic identity, whether or not in the fullest sense.

Now, Heinze wants to say that, as far as democratic ideals go, it would be better for a state to be an LSPD than a fragile democracy, and better to be an LSPD with uncompromised legitimacy than one like Sweden that sacrifices some of its democratic legitimacy by regulating hate speech. Our point, though, is that it's unclear how Heinze's account can vindicate this. If democratic ideals are merely hypothetical imperatives, as he says, then we're in no position to categorically insist that states should aspire to be democracies. But if we're unable to assert that states should be democracies, then equally, we're unable to 
say that states should be bold, uncompromising democracies, instead of half-hearted democracies, i.e. ones that allow concerns about the welfare of the vulnerable to take priority over unfettered discourse.

Heinze could try to manoeuvre here by saying that the half-hearted democracy loses all its legitimacy, not just a partial measure, and he flirts with that suggestion at various points. For instance, he says "there is no such thing as limiting one individual's citizenship in order to assure some other individual's citizenship" [50], and thus, he says, "the citizen prerogative of non-viewpoint-punitive expression within public discourse cannot admit of degrees" [50]. Likewise when he explains how democracy's legitimating conditions are unlike its 'optimising' conditions. There are many things we could do to promote the democratic flourishing of a state, and many of them come in degrees (e.g. the better a civic education program, the greater our democratic flourishing). But a legitimating condition of democracy is supposed to be different to this: "either it utterly succeeds or it utterly fails" [119]. This might seem odd, given Heinze's explicit statement that democratic legitimacy isn't entirely forfeited when a state fails to meet one of democracy's legitimating conditions. Heinze reconciles these two points, however, by saying that although the failure to meet one legitimating condition can be an all-or-nothing affair, the legitimacy of the democracy as a whole - given that there are a multiple legitimating conditions - isn't all-or-nothing. A democracy can meet some of its legitimacy conditions, while utterly failing one of them, and still be a legitimate democracy on the whole, despite there being a pro tanto delegitimating effect. In the end, then, Heinze isn't saying that a half-hearted democracy is illegitimate. And he's right to make this move, for in denying this one would end up being committed to the absurd claim that Sweden's rule over its citizens is no more democratically legitimate than North Korea's rule. ${ }^{26}$

One possible reply to the question - of why a democracy should be uncompromising instead of half-hearted - is to say that a democracy should simply aim to be as democratic as it can. But this takes us back to square one. If democratic ideals are hypothetical imperatives, then states need to be given some reason as to why they should aim to be as democratic as they can. Heinze wants his claims about democracy's requirements to get a purchase on states like Sweden, Canada, and the UK - the states "best situated today to fulfil a democracy's legitimating expressive conditions" but which "continue to impose

\footnotetext{
${ }^{26}$ Jeremy Waldron presses this kind of argument forcefully against a similar claim made by Dworkin. If legitimacy is an all-ornothing condition, and if anti-hate speech law robs a state of its legitimacy, then presumably Swedes are no more obliged to obey the law than North Koreans, which is implausible to anyone who isn't an anarchist. J. Waldron, The Harm in Hate Speech (Cambridge, Massachusetts: Harvard University Press, 2012).
} 
extensive viewpoint-selective penalties within public discourse" [215]. But in order to achieve this, he has to exit the realm of hypothetical imperatives, and provide us with some kind of story about why, on the balance of considerations, all societies should be aiming to realise the full-blooded vision of democracy, instead of being content with a half-hearted alternative.

The need for this additional piece in the argument is especially clear when we consider the radical nature of certain commitments that are entailed by Heinze's vision of democracy. In addition to getting rid of hate speech bans, states that join Heinze's democratic league would also have to abolish restrictions on incitement to violence, including incitement to terrorism. Heinze explicitly identifies and endorses this an upshot of the prerogative of non-viewpoint-punitive expression in public discourse. "The concept of 'incitement' is not merely vague at the 'periphery", he says, "it is unsustainable at the core" [173]. Heinze is led to this strident conclusion by the observation that political theories are always about violence, how it should be used, and against whom [166]. He isn't saying the law should ignore solicitation and criminal conspiracy, and other acts where there's an overt, causally proximate link between speech and violence, e.g. the cases where A says to B: "hey you, let's go and kill those people over there" [170-71]. His point is that there is a great deal of political speech which isn't overt in this manner, but which nevertheless does advocate violence - sometimes mass violence, sometimes against civilians - as part of a larger political struggle [173-175]. Heinze thinks that legally justifying crimes of incitement looks suspiciously like punishing public expression for the "unacknowledged crime of sheer expressive 'ugliness"', and so a democracy undermines its legitimacy in regulating speech on grounds of incitement [175]. And this returns us to our key question: why aspire to uncompromising democratic legitimacy if it entails this?

One way to argue that states have a good reason to try to realise Heinze's vision of democracy would be through some form of teleological argument. In adopting democratic systems of government, one might say, societies ascribe to themselves a political essence, which they then have reasons to try to fully nurture and realise. And thus, the argument would go, states like Sweden, Canada, and the UK, even though they currently restrict hate speech, have an essential nature - described in Heinze's vision of democracy - that would disallow such restrictions if those societies ever managed to realise their essential nature. Heinze seems to not want to make the case in this way, though. He derides what he calls 'the fallacy of historical and cultural determinism' [183], and argues against the notion that states have a teleology coded into in their histories like some sort of political DNA. One of his reasons for resisting such thinking is because of how it can be used to characterise a robust commitment to free speech as 
something that's native to an American conception of democracy, but alien to democracy as understood elsewhere. Heinze is unimpressed by claims about America's supposedly unique democratic essence. "From 1776 through to the 1960 s", he says, "the best that can be said is that the US was more or less democratic and rights-based depending on the locality" [185]. What accounts for the ascendance of free speech in the US, on his view, is the efforts of certain "legal visionaries" - like Justices Holmes, Brandeis, and Black - who, far from being feted as a vanguard of America's self-actualisation, were "vigorously opposed by a conservative as well as a racist and patriarchal establishment" [186]. Realising democracy in its boldest guise isn't about a society realising a prior essence. It is a struggle with no necessary historical trajectory, and no manifest destiny naturally tilting in favour of liberty.

But if the argument for Heinze's vision of democracy isn't a teleological one, what kind of argument can it be? It won't be much use to look to instrumental defenses of democracy, because even if they're cogent, it's unlikely that they will be fine-grained enough to ground a case for Heinze's particular version of democracy in preference to a half-hearted version of democracy that allows hate speech bans. One could instead try to make the case by invoking a non-instrumental justification for democracy - e.g. that it's the one form of government that duly respects the moral equality of citizens - but this would run the risk of supplying Heinze's opponents with tools to defend anti-hate speech law, as an outworking of the non-instrumental ideals that ground democracy in the first place.

What might do the trick, we think, in order to make the case Heinze needs to make, is some kind of appeal to ideas of hope and faith. Heinze is rightly suspicious about the mythmaking rhetoric of American democracy. But this rhetoric is an indication of the kind of argument that's called for in advocating a move to a more radically wide-open form of public discourse, in the face of genuine uncertainty about what the final results of doing this might be. Meiklejohn, one influential proponent of a democracy-based theory of free speech, expresses this kind of view when he says “...suppression is always foolish. Freedom is always wise. That is the faith, the experimental faith, by which we Americans have undertaken to live". ${ }^{27}$ Justice Holmes, one of the visionaries that Heinze credits for instituting strong free speech ideals in American law, gives us another example of this kind of hope-and-faith rhetoric in his classic dissent in Abrams. After arguing that the best way for people to try to get their views accepted is to present them for consideration in an open debate, rather than coercively imposing them on others,

${ }^{27}$ A. Meiklejohn, Political Freedom: The Constitutional Powers of the People (Oxford: Oxford University Press, 1965) 112. 
Holmes qualifies his point, saying

That, at any rate, is the theory of our Constitution. It is an experiment, as all life is an experiment.

Every year, if not every day, we have to wager our salvation upon some prophecy based upon imperfect knowledge. While that experiment is part of our system... we should be eternally vigilant against attempts to check the expression of opinions that we loathe... ${ }^{28}$

Holmes isn't issuing any guarantees here, about what kind of society an unfettered discussion of opinions will ultimately give birth to. He is calling for a leap of faith. That 'wagering of our salvation' may be partly inspired by what we know about the limitations of other forms of government. But it isn't premised on firm confidence about where democracy leads. In a recent discussion of this passage - speaking to the theme of "democracy's necessary faith in people" - Edwin Baker offers some intriguing reflections on Holmes's line of thought.

Given the lack of... certainty about the guess [as to] whether the suppression of freedom provides the best security, I think wisdom requires that choice favour liberty. Liberty is the choice if people are fundamentally good and worthy of respect; suppression is the choice if the opposite holds factually. We are worthy of intellectual attention and concern only if the former is true. For this reason, recognizing that the guess may turn out to be wrong, I would rather have hazarded the guess that justifies a concern with the circumstances and future of humanity. Only then would being right in the guess matter. ${ }^{29}$

Like Holmes, Baker is urging us to see that in subjecting ourselves to the outcome of wide-open democratic discourse, we have no guarantees against disaster. If it makes sense to do this, it's because it makes sense to hope that beings like us are truly capable of governing ourselves, or else - so Baker believes - there's nothing for it but despair. Baker makes his point melodramatically, but his argument is useful in getting to grips with Heinze's project. The historical conditions that made democracy possible in technologically-advanced nations, post-WWII, weren't inevitable. They have brought societies like ours to a point where real government by the people is within reach, along with all of the revolutionary

\footnotetext{
28 See Abrams v. United States, 250 U.S. 616 (1919).

${ }^{29}$ C. E. Baker, 'Autonomy and hate speech' in Ivan Hare and James Weinstein (Eds.), Extreme Speech and Democracy (Oxford: Oxford University Press, 2009) 157.
} 
possibilities - and perils - that this entails. Why not take the plunge and see if we can make it work? Why not take the free speech ideals that liberals have paid lip service to for decades, and see what happens if we commit to tolerating the expression of genuinely any viewpoint in public discourse? In taking that risk, maybe we will effect a decisive break with our political past, and usher in a new form of human society that embodies the best of us. ${ }^{30}$

The downside of making the case in those terms is that it treats Heinze's legitimating requirements of democracy as articles of faith. Heinze thinks he can do better than this. He argues that the LSPD has proven "distinctive in its capacity... to combat violence and discrimination against vulnerable groups, and to facilitate those groups' civic empowerment... without having to impose viewpoint-selective penalties within public discourse" [207]. It isn't a matter of faith to believe that non-viewpoint punitive societies will achieve social progress. We've already seen that progress playing out in LSPDs, over the last 60 years.

It is hard to see precisely how this type of historical argument can be cashed out, without collapsing back into the sort of historical determinism that Heinze critiques. Heinze speaks of a "democratic-historicism" which expresses its norms "not in the form of universalist algorithms transcending cultural contexts, but rather as emerging out of those contexts" [203]. The idea seems to be that in deciding what form of democracy we should try to realise, we shouldn't be appealing to a timeless, utopian, democratic ideal, but nor should we be making some facile extrapolation from our historical record. We should be doing something that avails itself of the insights of historicism, but without the methodological pitfalls.

Supposing such a method is viable, though, it's still hard to see how it could entitle us to read the historical record of LSPDs in a way that supports Heinze's conclusions. All of the LSPDs he mentions, apart from the US, impose hate speech bans in some form. We cannot infer that those societies have succeeded in combating discrimination without viewpoint-selective penalties, because it's possible that a part of how these societies have made progress in combatting discrimination is through their use of

\footnotetext{
30 This question, of whether a society is truly able to govern itself, echoes remarks one of Lincoln's early speeches. Speaking of the period of America's founding, Lincoln says: "through that period, it was felt by all, to be an undecided experiment... all that sought celebrity and fame, and distinction, expected to find them in the success of that experiment. Their all was staked upon it: their destiny was inseparably linked with it. Their ambition aspired to display... a practical demonstration of the truth of a proposition, which had hitherto been considered, at best no better, than problematical; namely, the capability of a people to govern themselves". A. Lincoln, Address before the Young Men's Lyceum (Springfield, Illinois, 27 January 1838).
} 
viewpoint-selective penalties. That leaves us to ask what lessons might be learned from America. Have the United States, since the 1960s, proven historically distinctive in their capacity to combat discrimination against vulnerable groups, and to facilitate those groups' empowerment, without imposing viewpoint-selective penalties in public discourse? Granted, any answers one might offer to this question will be open to debate. But, to put it mildly, there are plenty of social scientists who would tend to answer this question in the negative. And even for those who may have issued a more favourable assessment of the historical record c. 1960-2016, the era of Trump makes it very hard to accept optimistic progress narratives about post-war US race relations. ${ }^{31}$ This doesn't mean that Heinze's vision of democracy is untenable. States that restrict hate speech have likewise seen surges in racial hostility in recent years. Our point is that, given the historical examples that can be appealed to in this context, Heinze - and his fellow travellers who oppose the banning of hate speech in the name of democratic legitimacy - cannot look to history for reassurance. The historical record doesn't inoculate them or us against the risks that are incurred in allowing political discourse to be genuinely unfettered and wide-open. If those risks are to be incurred, it will involve some leap of faith. The LSPDs that refrain from taking that leap of faith are still democracies, and can still - by Heinze's own lights - keep most of their democratic legitimacy intact. Their reluctance to take that leap of faith stems from a fear of where it all might lead. As far as the historical record goes, that fear is reasonable. But so is hope.

\section{What about the victims of democracy?}

Ultimately, Heinze's argument rests on a claim about the essence of democratic citizenship. This understanding of democratic citizenship has certain merits, as well as certain difficulties and limitations that we've canvassed in our discussion. In closing, though, it is important to reflect on where a view like this would leave a society, if it could satisfy the challenges we've raised. Heinze's view implies that some people will have to suffer the indignity of being attacked with hate speech that is legally tolerated in the name of democracy. What can the state say by way of justification to these people - these victims of

\footnotetext{
31 As we've mentioned, Heinze doesn't see the US as a perfect model democracy. Our claim here is that Heinze's view implicitly relies on a claim about the open society's ability to overcome hate. Since that claim isn't fully amenable to empirical verification, it functions like a leap of faith, or at least a kind of optimism, that has often been associated with American jurisprudence, for better or for worse.
} 
democracy?

Compare, for example, the replies that Heinze's account would allow two different societies - an LSPD like Canada, and a non-LSPD like India - to make to a Muslim citizen being vilified with hate speech. In India, when a victim asks why he should have to absorb this sort of abuse, one available reply would be: "your suffering is unacceptable and will not be tolerated, because we see the prevention of this abuse through hate speech bans as necessary in order to be a legitimate state". ${ }^{32}$ But in Canada, or any LSPD, this reply shouldn't be available, according to Heinze's view. In Canada, Heinze thinks, the reply should be something like: "this abuse must be tolerated, because only by tolerating this abuse and whatever suffering it causes to you and others like you can we uphold our democratic legitimacy". One way of hearing this response is that attaining democratic legitimacy is worth the foreseeable suffering of victims. Even though Heinze would resist this kind of balancing rationale, he tacitly admits that the harms in question are eligible for balancing when he claims that they warrant a sacrifice of some democratic legitimacy in non-LSPDs. He concedes that hate speech related harms are important: the harms can properly be weighed against the value of democratic legitimacy and found wanting. ${ }^{33}$ In many cases the pursuit of democratic legitimacy can be sacrificed, since it is not a source of categorical imperatives. But not in an LSPD: the imperative is hypothetical, but it is an imperative. So the reply given to the Canadian Muslim by his society, at a foundational level, must be that attaining democratic legitimacy has overriding importance relative to his suffering.

This claim can be elaborated, broadly, in two ways: "avoiding harm to you by sacrificing democratic legitimacy isn't worth it", or "we are the sort of society that, by its nature, is entitled to secure its legitimacy in ways that tolerate harms inflicted on you". If Heinze takes the first option, then it seems

\footnotetext{
32 An alternative answer might be: "we're aspiring to both democratic and state legitimacy, and the current balancing jurisprudence led to unintended results, whose unacceptability means the balance should be recalibrated".

${ }^{33}$ Heinze spends considerable time denying that hate speech has been shown to cause harms in LSPDs, and so here we don't mean to be entering that debate. What we refer to as "abuse" and "suffering" is whatever negative consequences redound to the targets of hate speech. We take it that Heinze acknowledges these consequences, because they are the very thing that must be aggressively countered by the "active" democracy that he insists on, one that promotes a pluralist agenda through the organs of the state. So to whatever degree state promotion of pluralism counteracts those negative consequences, some of it will still occur on the margins, and so there will still be victims. Our point is that it is disquieting to imagine what gets said to those victims when they experience the negative consequences, and thus how we expect victims to view the tacit logic of us tolerating their abuse in the name of democracy.
} 
that he is engaging in a sort of balancing of different legitimacy dimensions, whereas he wants to resist a balancing approach to speech curtailment. But if he takes the second option, as seems likely, then the underlying logic looks disturbing. It amounts to a group saying to one of its members "our group identity is so overridingly important that we are permitted to allow certain individuals or subgroups to suffer abuse". In turn, this implies that the group's sense of identity is considered to be overridingly important, compared to the harms that upholding this identity foreseeably leads to. ${ }^{34}$

One might try to avoid this identity-based elaboration by putting it in terms of collective selfdetermination. But that would have the group say, "we get to impose our will on you about what our group identity is, regardless of the bad results for you". Heinze might protest that his calculus doesn't license this because sufficient levels of harm, aggregated over time, will cancel the LSPD status. But this requires viewing things from a spatial and temporal distance, considering the sweep of history from a third-person perspective. Since there will always be victims on the margins, they are entitled to ask why the legal system didn't protect them by the means at its disposal. And pointing to the historical category of LSPD isn't a satisfactory response to a particular Muslim victim by a particular LSPD society. Insofar as an LSPD is engaged in a justificatory enterprise with those subject to its laws, Heinze's view implies a dialectical stance that elevates the identity of a group over the interests of individuals. This seems a high price to pay in order to avoid a balancing approach to hate speech.

In fact, we believe that Heinze's own account ultimately cannot do without some forms of values-balancing. First, societies on the borderline of LSPD status must balance their pursuit of state legitimacy and democratic legitimacy. Second, even for secure LSPDs the public-private boundary must be determined through a process of law, which involves judgments about competing values: Heinze himself says, "delineating the borders of these spheres is difficult... and requires legislators and judges" [85]. And third, Heinze reveals a willingness to admit balancing when he advocates two exceptions to non-viewpoint-punishment absolutism in LSPDs: primary schools and workplaces. He says "banning hate speech within early education, like banning it from workplaces, forms part of the active democracy's prerogative to promote pluralist values" [113]. Heinze defends these encroachments on the prerogative because they help "to empower vulnerable groups... it teaches them to 'answer back' in public discourse,

\footnotetext{
34 An analogous case would be if a society were to say, "A system of property rights (or capitalism) is more important than the degradation caused to individuals or groups by the predictable poverty that ensues, because it is essential to our identity as a liberal state".
} 
with the views of a pluralist state backing them" [113]. But this sort of defense undermines absolutism. Any defense in terms of citizens' capacities will necessarily undercut absolutism, because it must admit that speech curtailment in public spaces is necessary for preserving the preconditions for democratic citizenship. As soon as the preservation of and the exercise of a key capacity (expression) can come into conflict, we face a balancing problem. So in the end, rather than showing how democratic citizenship is an alternative to balancing as a basis for legitimacy, Heinze implicitly relies on balancing in his linking of expression to citizenship.

\section{Conclusion}

In these reflections we have scrutinized Heinze's core thesis: a citizen's expressive prerogative deserves special protection because it corresponds to what is constitutive of democracy, and so any legal restriction of this prerogative compromises democratic legitimacy. We have argued that although the view is innovative and provocative, it faces significant challenges. There are practical implications of the view that will trouble many democratic theorists, and there are also difficulties at the theoretical level. Heinze is under more pressure than he admits to defend the value of democracy against other political values involved in assessments of legitimacy. Partly this is because the elements of state and democratic legitimacy are not as clearly distinguishable as he assumes, and hence it is questionable whether a domain of democratic legitimacy can be isolated from other elements of legitimacy as such. But it's also because any constitutivist approach to understanding democratic legitimacy - one that at the same time acknowledges other factors in overall political legitimacy - owes us an account of how those other things can be responsibly pursued alongside the requirements of democracy. Heinze gives us some reason to hope that they can, but not to insist that they can. 